\title{
Empleo de materiales secundarios como materia prima de nuevos tipos de cementos
}

\author{
Secondary raw materials for synthesising \\ new kind of cements
}

\author{
S. GOÑI, A. GUERRERO, Mª. MACÍAS, R. PEÑA y E. FERNÁNDEZ ESCALANTE \\ Instituto de Ciencias de la Construcción Eduardo Torroja (CSIC)
}

Fecha de recepción: 28-V-2001

ESPAÑA

\section{RESUMEN}

Este trabajo es un estudio comparativo de algunas de las características de nuevos cementos belíticos, obtenidos a partir de dos tipos de residuos, como materia prima secundaria: cenizas volantes (CV) de bajo contenido en cal, procedentes de la combustión del carbón y cenizas procedentes de la incineración de residuos sólidos urbanos (CIRSU). Los cementos fueron sintetizados en un rango de temperaturas comprendido entre $700{ }^{\circ} \mathrm{C}$ y $900{ }^{\circ} \mathrm{C}$ después de un tratamiento hidrotermal de la CV y CIRSU a $200^{\circ} \mathrm{C}$. La evolución de las fases cementícias, con la temperatura de calentamiento, fue estudiada por difracción de rayos $X$ (DRX). Los resultados fueron comparados con aquellos obtenidos, directamente, por calentamiento de los residuos, sin un tratamiento hidrotermal previo de los mismos. El grado de hidratación fue cuantitativamente evaluado, por medio del análisis termogravimétrico, a partir del agua combinada de los cementos hidratados durante un periodo de 28 dias o 200 días, dependiendo de la cinética de hidratación de cada cemento.

\section{SUMMARY}

The present paper is a comparative study of some characteristics of new belite cements obtained from two kind of wastes, which were used as secondary raw materials: fly ash (FA), of low $\mathrm{CaO}$ content, from coal combustion, and ash from incineration of municipal solid waste (MSWIA). Cements were synthesised in a range of temperature between $700{ }^{\circ} \mathrm{C}$ and $900{ }^{\circ} \mathrm{C}$ from MSWIA and $F A$, which were previously activated by hydrothermal treatment at $200^{\circ} \mathrm{C}$. The evolution of cemented phases with the heating temperature was followed by $X$-ray diffraction (XRD). The results were compared with those obtained from heating the starting FA and MSWIA without the previous hydrothermal treatment. The degree of hydration was quantitatively evaluated by the combined water content, determined from thermogravimetric analyses, during a period of 28 days or 200 days from mixing depending of hydration kinetics of each cement.

\section{INTRODUCCIÓN}

Entre los motivos que están impulsando actualmente el desarrollo de nuevos tipos de materiales, se encuentran las mejoras de sus propiedades y las exigencias medioambientales, cada vez más restrictivas, durante el proceso de su fabricación. En el caso del cemento Portland, la contaminación ambiental, principalmente de emisión de $\mathrm{CO}_{2}$, que se produce en el proceso tradicional de su fabricación junto con la preservación de las materias primas naturales están promoviendo, a una escala mundial y en particular en nuestro

\section{INTRODUCTION}

Among the reasons which are actually promoting the development of new materials are both their higher performances and the environment restrictions of their fabrication processes. In the case of ordinary Portland cement, the great amount of $\mathrm{CO}_{2}$ emission, produced during its traditional fabrication, together with the great amount of natural raw materials consumption, are promoting investigations related to 
laboratorio, investigaciones para la obtención de nuevos cementos belíticos, en cuyos procesos de fabricación se empleen materias primas y procesos industriales, respetuosos con el medio ambiente y económicamente viables, que eviten o al menos reduzcan los mencionados problemas medioambientales.

En este sentido, la utilización de sub-productos y residuos industriales como materias primas alternativas está incrementando considerablemente. Así, por ejemplo, los residuos industriales procedentes de un proceso de combustión de lecho fluidizado contienen fases potencialmente reactivas como cal, sulfatos y alúmina, a partir de las cuales se puede fabricar cementos expansivos, denominados cementos de sulfoaluminato cálcico (1).

Las cenizas volantes, que se generan en un proceso de combustión de carbón, son otro tipo de residuo que puede ser empleado como materia prima para la fabricación de cementos (2-12). Esta nueva aplicación surgió ante las expectativas de demanda de energía para usos industriales y domésticos en un futuro cercano, estimándose que en el año 2010 la producción de dichas cenizas volantes será de 800 Mega toneladas, con los problemas medio ambientales derivados de su almacenamiento que esta gran producción implicará.

Jiang y Roy, en el año 1992, fueron pioneros en el empleo de las cenizas volantes como materia prima para la fabricación de un cemento de baja energía, denominado Cemento Belítico de Ceniza Volante (CBCV). El método de fabricación incluía un pretratamiento hidrotermal de las cenizas durante el cual se forman las fases hidratadas precursoras del cemento. La deshidratación posterior, por calentamiento controlado de dichos precursores, da lugar a fases cementícias altamente reactivas, tipo belita.

Los cementos belíticos tradicionales están constituidos fundamentalmente por la variedad estructural $\beta$ del silicato bicálcico (belita), compuesto que, por las vías tradicionales, se obtiene a partir de las mezclas de $\mathrm{CaCO}_{3}$ y arcilla, calentadas hasta $1.350^{\circ} \mathrm{C}$. Este tipo de cemento tiene unas propiedades, diferenciadas del cemento Portland ordinario, necesarias para determinadas aplicaciones. En primer lugar presenta una cinética de hidratación más lenta, por lo que el calor que se libera es más gradual, evitándose problemas de retracción. Esta circunstancia lo hace idóneo para la fabricación de grandes bloques de hormigón en masa, como es el caso de las presas. En segundo lugar, es un cemento más estable microestructuralmente que el cemento Portland, frente new belite cements, through environmental friendly process, which avoid or at least decrease the problems aforementioned.

In this sense, the use of industrial waste and byproducts as alternative secondary raw materials is increasing considerably. For example, the industrial waste, from fluidised bed combustion, contains potential reactive phases such as: lime, sulphate and alumina from which it is possible to fabricate expansive cements, called calcium sulfo-aluminate cements (1).

Fly ash from coal combustion is another kind of waste to be used as raw material for synthesising cements (2-12). This new application was developed due to the production of large volumes of fly ash, from the demand for industrial and domestic energy, which will increase on an unprecedented scale in the coming years (800 x $10^{6}$ tons by the year 2010). Therefore fly ash should not only be disposed of safely to prevent environmental pollution, but should be treated as a valuable resource.

Jiang and Roy, in the year 1992, for the first time used fly ash from coal combustion as raw material for synthesising low-energy cement, called Reactive Fly Ash Belite Cement (FABC). The fabrication process included a pre-hydrothermal treatment of the fly ash, where the hydrated precursors of the cement were obtained. The posterior dehydration of those phases, by controlled heating, gives rise to the highly reactive belite phases.

The traditional belite-cement is basically constituted by the $\beta-C_{2} S$ structural variety, compound which is obtained in the traditional way from a mixture of $\mathrm{CaCO}_{3}$ and clay, heated at $1.350^{\circ} \mathrm{C}$. This kind of cement as some different properties from the ordinary Portland cement, which are necessary in some applications. First, the hydration kinetic is slower, so the heat liberated is more gradual, avoiding retraction problems. This characteristic makes it useful to manufacture big concrete blocks, as in the case of dams. Second, this cement is more stable in determinate 
a determinados procesos agresivos que transcurren en medios altamente alcalinos.

Debido a estas propiedades, se están llevando a cabo numerosas investigaciones para aumentar la reactividad de la fase belita y conseguir mejores prestaciones mecánicas. Entre ellas, parece que el mejor resultado se obtiene por métodos de síntesis denominados de baja energía, junto con la incorporación de estabilizantes en la red del silicato bicálcico: álcalis ( $\mathrm{Na}$ y K), Fe ó Al. Estas circunstancias se dan en el método propuesto por Jiang y Roy (2).

Dicha metodología fue aplicada en nuestro laboratorio para el caso de cenizas volantes españolas de bajo contenido en cal (3-10). Durante el tratamiento hidrotermal $\left(200^{\circ} \mathrm{C}\right.$ durante 4 horas y $1,25 \mathrm{MPa}$ de presión) se forman mayoritariamente unas fases hidratadas tipo $\alpha-\mathrm{C}_{2} \mathrm{SH}$, gel CSH y katoita $\left(\mathrm{C}_{3} \mathrm{ASH}_{4}\right)$ que son las precursoras del cemento. La deshidratación posterior, por calentamiento controlado de dichas fases precursoras favorece la formación de fases altamente reactivas en el cemento final a una temperatura de $800^{\circ} \mathrm{C}$, alcanzando a los 28 días valores de resistencia equiparables a un cemento Portland, tipo CEM I-32.5 (7).

Además, de los estudios de durabilidad de morteros de dicho cemento, en un medio agresivo mezcla de sulfato y cloruro sódico ambos de concentración 0,5 M (48. $000 \mathrm{ppm})$ (muy por encima de la concentración de sulfato de $2.000 \mathrm{ppm}$, establecida como causante de ataque severo en el hormigón), se vio que el material era microestructuralmente resistente a dicho medio agresivo, teniendo en cuenta, además, la alta proporción de fases alumínicas y, por lo tanto, vulnerables al ataque por sulfato, del cemento $(5,10)$.

Otro tipo de residuos que puede ser empleado como materia prima secundaria son los procedentes de la incineración de residuos sólidos urbanos. En la Comunidad Europea (CE) se producen anualmente del orden de 200 Mega toneladas de estos residuos, cantidad que, teniendo en cuenta el aumento de población del $40 \%$ estimado para el año 2015 , sobrepasará sustancialmente las medidas de control, almacenamiento etc., actualmente vigentes en la $\mathrm{CE}$ para estos residuos.

Por lo tanto, se están llevando a cabo numerosas investigaciones, sobre la búsqueda de aplicaciones potenciales de dichos residuos en el campo de la construcción: como áridos $(13,14)$, bloques de construcción (15), en carreteras $(16,17)$, etc. Entre los principales inconvenientes de estas aplicaciones se encuentran la expansión y su alto contenido en aggressive processes in a very high alkaline environment.

Due to these advantages, numerous investigations are being carried out to increase the reactivity of belite phase and therefore to increase its mechanical performance. From these investigations consensus has been reached on "low temperature synthesis" together with incorporation of alkalis $(\mathrm{Na}, \mathrm{K}), \mathrm{Fe}$ or $\mathrm{Al}$ in the $\mathrm{C}_{2} S$ structure are the best ways to allow a very reactive $C_{2} S$. All these circumstances are given in the case of fly ash and in the hydrothermal treatment proposed by Jiang and Roy (2).

The Jiang and Roy methodology was applied in our laboratory, with some modifications, for the case of Spanish fly ash of low $\mathrm{CaO}$ content (3-10). During the hydrothermal treatment $\left(200{ }^{\circ} \mathrm{C}\right.$ for 4 hours and $1.24 \mathrm{MPa}$ of pressure) the fly ash pozzolanic reaction is strongly activated leading to hydraulic products: katoite $\left(\mathrm{C}_{3} \mathrm{ASH}_{4}\right)$ $\left(\mathrm{Ca}_{3} \mathrm{Al}_{2}\left(\mathrm{SiO}_{4}\right)(\mathrm{OH})_{8}\right)$ together with $\mathrm{CSH}$ gel $\left(\mathrm{Ca}_{1.5} \mathrm{SiO}_{3.5} \mathrm{xH}_{2} \mathrm{O}\right)$ and $\alpha-\mathrm{C}_{2} \mathrm{SH}$, which are the precursors of the cement. In a second step those precursors are dehydrated by heating at $800^{\circ} \mathrm{C}$. The cement so obtained reached, at 28 days, compressive strength value similar to that of Portland cement type CEM I-32.5 (7).

Besides, the cement is very resistant to severe sulfate attack, as the durability study in sulfate aggressive solution of 48.000 ppm of sulphate concentration (higher than the $2.000 \mathrm{ppm}$ sulfate concentration established as the cause of severe attack in concrete) demonstrated $(5,10)$, taking into account the great amount of aluminate of starting fly ash, and therefore suitable to sulfate attack.

Another kind of residues to be used as secondary raw material are those from municipal solid waste incineration. The European Community (EC) produces yearly $200 \times 10^{6}$ tons of MSWIR, which, taking into account the increase of $40 \%$ of population estimated by the year 2015, will over the actually EC previsions on MSWIR storage and control measurements.

For this, numerous investigations are being carried out on the search of potential applications of MSWIR on the construction field: Examples are as in aggregate replacing natural gravel in the production of a concrete $(13,14)$, construction blocks (15), in asphalt for road constructions $(16,17)$, etc. Nevertheless, the expansion and the high chloride 
cloruros, por lo que los residuos tienen que ser tratados previamente a su incorporación en los materiales de construcción (18-23).

Debido a que estos residuos, contienen además de $\mathrm{Cl}$, elementos como $\mathrm{Ca}, \mathrm{Si}, \mathrm{Al}, \mathrm{y} \mathrm{S}$, pueden ser empleados como materia prima para la fabricación de cementos especiales tipo sulfo-belíticos (24); de alinita (25), de fases con propiedades hidráulicas como el cloroaluminato cálcico (26) y reemplazando parcialmente las materias primas naturales del cemento Portland, después de su des-salinización (27, 28).

Aprovechando los conocimientos adquiridos por nuestro grupo de investigación, a través de la fabricación de cemento belítico de ceniza volante (CBCV), se pensó que podía dar buen resultado en el caso de las cenizas de incineración de residuos sólidos urbanos(CIRSU).

El presente trabajo es un estudio comparativo de algunas características de los cementos, que hemos obtenido en el laboratorio, a partir de los dos tipos de residuos: cenizas de bajo contenido en cal, procedentes de la combustión de carbón y cenizas procedentes de la incineración de residuos sólidos urbanos.

\section{PROCEDIMIENTOEXPERIMENTAL}

\subsection{Materiales}

Ceniźas volantes, procedentes de la combustión de carbón (denominadas CV) y de la incineración de residuos sólidos urbanos (denominadas CIRSU), fueron empleadas como materia prima para la fabricación de los nuevos cementos. La composición química y mineralógica de ambos residuos se da en la Tabla 1 y Figura 2, respectivamente. En el caso de la CV (Fig. 2 (a)), las principales fases cristalinas son: $\alpha-\mathrm{SiO}_{2}$ y mullita $\left(\mathrm{Al}_{6} \mathrm{Si}_{2} \mathrm{O}_{13}\right)$, la ceniza cumple con los requerimientos del tipo $\mathrm{F}$ de la clasificación ASTM: contenidos de $\mathrm{SiO}_{2}+\mathrm{Al}_{2} \mathrm{O}_{3}+\mathrm{Fe}_{2} \mathrm{O}_{3}$ superiores al $70 \%$, y bajo contenido en cal, como se puede ver en la Tabla 1.

La CIRSU proviene del sistema de depuración de gases y por lo tanto tiene elevado contenido en $\mathrm{Ca}^{2+}$ (procedente de la cal utilizada como absorbente); asimismo, las cantidades de cloruro y $\mathrm{SO}_{3}$ son significativas. Sus fases cristalinas mayoritarias (Fig. 2 (a')) son: $\mathrm{NaCl}$ (halita), $\mathrm{KCl}$ (silvita), $\mathrm{CaCl}_{2} \cdot \mathrm{Ca}(\mathrm{OH})_{2} \cdot \mathrm{H}_{2} \mathrm{O}, \mathrm{CaSO}_{4}$ (anhidrita), $\mathrm{Ca}(\mathrm{OH})_{2}$ (portlandita), $\mathrm{CaCO}_{3}$ (calcita) y $\mathrm{Ca}_{2} \mathrm{Al}_{2} \mathrm{SiO}_{7}$ (gelenita). Las minoritarias: $\mathrm{Fe}_{2} \mathrm{O}_{3}, \alpha-\mathrm{SiO}_{2}, \mathrm{Al}$ metálico y probablemente $\mathrm{C}$ y $\mathrm{Mg}_{2} \mathrm{C}$. content are serious problems of these wastes, which must to be treated prior to its incorporation in construction (18-23).

Before chloride, MSW incineration residues contains elements as $\mathrm{Ca}, \mathrm{Si}, \mathrm{Al}$ and $\mathrm{S}$, which can be used as secondary raw material for special cements containing hydraulic materials such as sulfo-belite (24); alinite (25), or calcium chloroaluminate (26), and Portland cements, after desalinising of incineration ash by washing with water $(27,28)$.

Taking in to account our knowledge on the fabrication of fly ash belite cement, we thought to extend it to municipal solid waste incineration residues.

The present paper is a comparative study of some characteristics of the cements obtained by us from two kind of wastes: fly ash, of low $\mathrm{CaO}$ content, from the coal combustion and ash from the incineration of municipal solid waste.

\section{EXPERIMENTAL PROCEDURE}

\subsection{Materials}

Fly ash from both coal combustion (named FA) and from incineration of municipal solid waste (named MSWIFA) were used as secondary raw materials for synthesising new cements. Their chemical and mineralogical compositions are given in Table 1 and Fig. 2, respectively. In the case of $F A$ (Fig. 2 (a)), the main crystalline phases are: $\alpha-\mathrm{SiO}_{2}$ and mullite $\left(\mathrm{Al}_{6} \mathrm{Si}_{2} \mathrm{O}_{13}\right)$, the $\mathrm{FA}$ is in accordance with the requirements of ASTM Class $F$ and the EN-UNE 450 specifications: $\mathrm{SiO}_{2}+\mathrm{Al}_{2} \mathrm{O}_{3}+\mathrm{Fe}_{2} \mathrm{O}_{3}$ contents higher than $70 \%$ and low $\mathrm{CaO}$ content, as it can be seen in Table 1.

The MSWIA coming from the gas cleaning device and therefore has high $\mathrm{Ca}^{2+}$ content (from the $\mathrm{CaO}$ used as adsorbent), high chloride and high $\mathrm{SO}_{3}$ content. The main crystalline compounds (Fig. $2\left(a^{\prime}\right)$ ) are the following: $\mathrm{NaCl}$ (halite), $\mathrm{KCl}$ (sylvite), $\mathrm{CaCl}_{2} \cdot \mathrm{Ca}(\mathrm{OH})_{2} \cdot \mathrm{H}_{2} \mathrm{O}, \mathrm{CaSO}_{4}$ (anhydrite), $\mathrm{Ca}(\mathrm{OH})_{2}$ (portlandite), $\mathrm{CaCO}_{3}$ (calcite) and $\mathrm{Ca}_{2} \mathrm{Al}_{2} \mathrm{SiO}_{7}$ (gehlenite). The minority phases are the following:

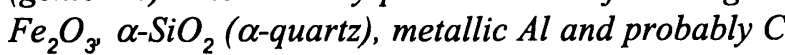
and $\mathrm{Mg}_{2} \mathrm{C}$. 
TABLA $1 /$ TABLE 1

Composición Química de las Cenizas Volantes (CV) y de Incineración de Residuos Sólidos Urbanos (CIRSU) (\% en peso)

(Chemical Composition of Fly Ashes (FA) and Ashes from Municipal Solid Waste Incineration (MSWIA) (\% by weight)

\begin{tabular}{|c|c|c|}
\hline & $\begin{array}{c}\text { CIRSU } \\
(M S W I A)\end{array}$ & $\begin{array}{c}\text { CV } \\
\text { (FA) }\end{array}$ \\
\hline $\mathrm{PF}(\mathrm{LOI})$ & 17.6 & 5.6 \\
\hline $\mathrm{RI}($ IR) & 0.1 & 0.3 \\
\hline $\mathrm{CaO}$ & 44.9 & 4.65 \\
\hline $\mathrm{SiO}_{2}$ & 11.4 & 48.8 \\
\hline $\mathrm{Al}_{2} \mathrm{O}_{3}$ & 11.3 & 26.8 \\
\hline $\mathrm{Fe}_{2} \mathrm{O}_{3}$ & 1.1 & 7.45 \\
\hline $\mathrm{MgO}_{\mathrm{SO}}$ & 1.9 & 1.9 \\
\hline $\mathrm{SO}_{3}$ & 3.9 & 0 \\
\hline $\mathrm{Na}_{2} \mathrm{O}$ & 2.1 & 0.67 \\
\hline $\mathrm{K}_{2} \mathrm{O}$ & 1.9 & 3.65 \\
\hline $\mathrm{Cl}^{-}$ & 13 & \\
\hline Blaine(cm $\left.{ }^{2} / \mathrm{g}\right)$ & 7275 & 4998 \\
\hline Densidad & 2.55 & 2.11 \\
(Density)(g/cc) & & \\
\hline
\end{tabular}

PF = Pérdida al Fuego; RI = Residuo Insoluble ( $L O I=$ LOss on ignition; $I R=$ Insoluble residue $)$

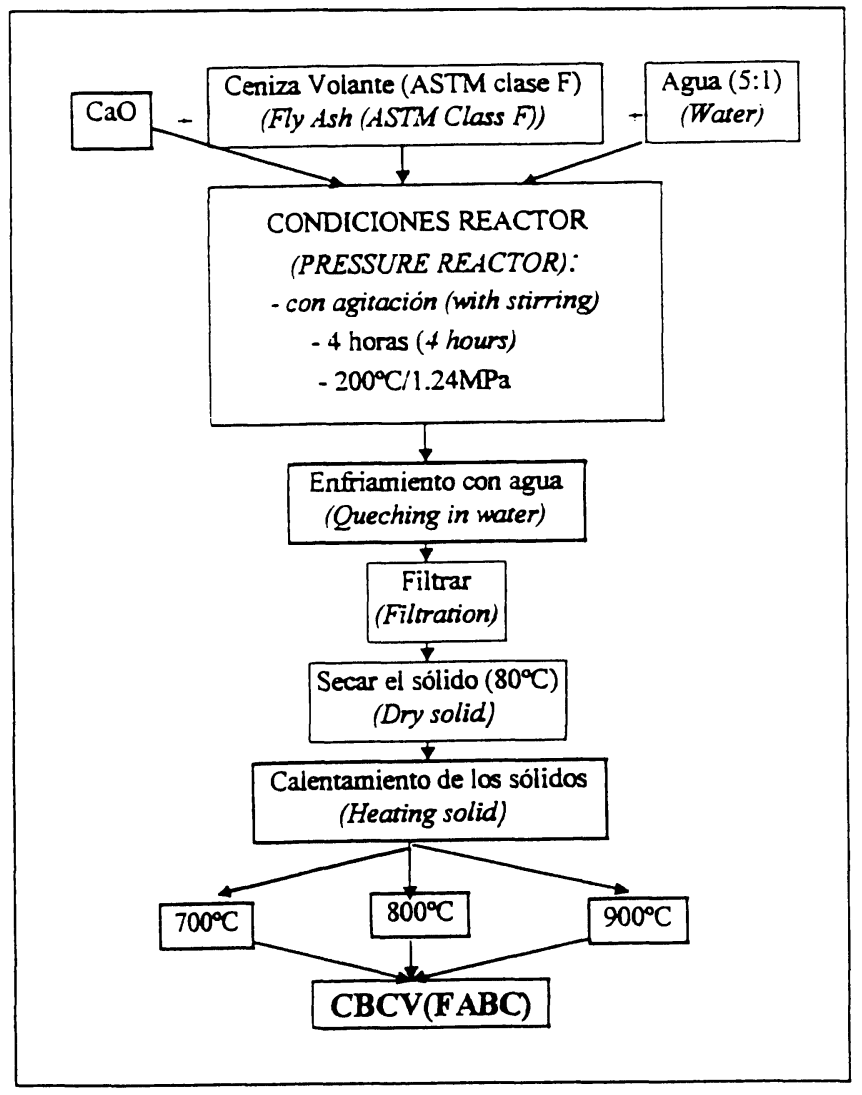

Figura 1.- Esquema del proceso de sintesis del cemento belítico.

Figure 1.- Scheme of the FABC synthesis process. 


\subsection{Procedimiento de síntesis de los cementos}

El esquema del proceso global de síntesis del cemento se ilustra en la Fig. 1. En el caso de la CV fue necesario un aporte de cal en una proporción molar $\mathrm{Ca} / \mathrm{Si}$ de 2 para obtener cemento belítico. La CIRSU se utilizó tal cual, sin aporte adicional de cal. La mezcla de ceniza volante, cal y agua fue tratada hidrotermalmente a $200^{\circ} \mathrm{C}$ y $1,24 \mathrm{MPa}$ de presión durante 4 horas, con agitación constante. Después de ese tiempo, el reactor se enfrió y el sólido se filtró y secó a la temperatura de $80^{\circ} \mathrm{C}$. El producto seco fue posteriormente calentado hasta $600^{\circ} \mathrm{C} \mathrm{a}$ una velocidad de calentamiento de $10^{\circ} \mathrm{C} / \mathrm{min}$ y desde $600^{\circ} \mathrm{C}$ hasta $700^{\circ} \mathrm{C}, 800^{\circ} \mathrm{C}$ y

$900^{\circ} \mathrm{C}$ a una velocidad de $5^{\circ} \mathrm{C} / \mathrm{min}$. En el caso de la CIRSU, el tiempo de permanencia en el reactor fue de 1 hora, pues a tiempos mayores no se produce ningún cambio, tanto en el sólido como en la disolución (22).

\subsection{Métodos de análisis}

El tratamiento hidrotermal se llevó a cabo en un reactor Parr, 4.522 (bomba de $1.000 \mathrm{ml}$ con agitador y controlador de temperatura 4842). Los análisis por difracción de rayos $\mathrm{X}$ se efectuaron con un difractómetro Philips PW 1730; radiación $K \alpha_{1}$ de $\mathrm{Cu}$ y monocromador de grafito. El análisis térmico fue llevado a cabo con un equipo Netzsch dotado de un sistema de análisis simultáneo STA 409. La cantidad de muestra fue de $50 \mathrm{mg}$, corriente de $\mathrm{N}_{2}$ (flujo de $100 \mathrm{~cm}^{3} / \mathrm{min}$ ) y una velocidad de calentamiento de $10^{\circ} \mathrm{C} / \mathrm{min}$.

\section{RESULTADOS Y DISCUSIÓN}

\subsection{Evolución de los residuos con la temperatura de calentamiento}

La evolución de los residuos CV y CIRSU con la temperatura puede verse en la Fig. 2. La mezcla de CV y cal (Fig. 2 (c)) no experimenta cambios apreciables después de haber sido calentada a $900^{\circ} \mathrm{C}$. Sin embargo, la CIRSU ya reacciona a $700^{\circ} \mathrm{C}$ (Fig. 2 (b'), desapareciendo las reflexiones de $\mathrm{CaCl}_{2} \cdot \mathrm{Ca}(\mathrm{OH})_{2} \cdot \mathrm{H}_{2} \mathrm{O}$, portlandita y $\mathrm{Al}$ metálico y disminuyendo la intensidad de las reflexiones de la anhidrita y gelenita. A esa temperatura se detectan las siguientes fases: mayenita $\left(C_{12} A_{7}\right), C_{3} A$ y $\beta-C_{2} S$ (ficha JCPDS No. 33-302). Entre $700^{\circ} \mathrm{C}$ y $900^{\circ} \mathrm{C}$, la mayenita y $\beta-\mathrm{C}_{2} \mathrm{~S}$ aumentan, y empiezan a formarse: $\mathrm{Ca}_{10}\left(\mathrm{SiO}_{4}\right)_{3}\left(\mathrm{SO}_{4}\right)_{3} \mathrm{Cl}_{2}\left(\mathrm{C}_{10} \mathrm{~S}_{3} \mathrm{~s}_{3} \mathrm{Cl}_{2}\right)$; alinita

\subsection{Cement synthesis procedure}

The scheme of the synthesis process is shown in Fig. 1. In the case of FA, it was necessary to add $\mathrm{CaO}$ in a $\mathrm{Ca} / \mathrm{Si}$ molar ratio of 2 to obtain the belite cement. The MSWIA was used without extra $\mathrm{CaO}$. The fly ash/CaO mixture was first treated hydrothermally at $200^{\circ} \mathrm{C}$ and $1.24 \mathrm{MPa}$ pressure for 4 hours. De-mineralised water was used in this process at a water-to-solid ratio of 5, with continuous stirring. After four hours of heating, the reactor was cooled and the solids filtered and dried at $80^{\circ} \mathrm{C}$. The dried product was then heated at a rate of $10^{\circ} \mathrm{C} / \mathrm{min}$ (up to $600{ }^{\circ} \mathrm{C}$ ), and $5^{\circ} \mathrm{C} / \mathrm{min}$ from $600{ }^{\circ} \mathrm{C}$ to $700^{\circ} \mathrm{C}$, $800^{\circ} \mathrm{C}$ and $900^{\circ} \mathrm{C}$. In the case of MSWIA, the time of hydrothermal treatment was 1 hour, because of a plateau of stabilisation, in both the liquid and solid compositions, was reached after 1 hour (22).

\subsection{Analytical methods}

The hydrothermal treatment was carried out with a Parr pressure reactor equipment Model 4522 (1.000 ml pump with split-ring closure and a 4842 temperature controller). XRD patterns were recorded on a Philips PW 1730 diffractometer with a graphite monochromator and $\mathrm{Cu} K \alpha_{1}$ radiation. The thermal analyses were recorded using a Netzsch equipment with STA 409 simultaneous analysis system using $50 \mathrm{mg}$ samples and a dynamic nitrogen stream (flow rate $=100 \mathrm{~cm}^{3} / \mathrm{min}$ ) at a heating rate of $10^{\circ} \mathrm{C} / \mathrm{min}$.

\section{RESULTS AND DISCUSSION}

\subsection{Evolution with heating of starting wastes}

The evolution with heating of the two wastes can be seen in Fig. 2. The $\mathrm{CaO}$ and FA mixture does not change after heating at $900^{\circ} \mathrm{C}$ (Fig. 2 (c)). Nevertheless, the MSWIA changed at $700^{\circ} \mathrm{C}$ where the $\mathrm{CaCl}_{2} \cdot \mathrm{Ca}(\mathrm{OH})_{2} \cdot \mathrm{H}_{2} \mathrm{O}$, portlandite and metallic aluminium reflections disappeared (Fig. $2\left(b^{\prime}\right)$ ) and the intensity of those corresponding to anhydrite and gehlenite decreased and shifted to higher $2 \theta$ angular zone, in the case of anhydrite, and to lower $2 \theta$ angular zone, in the case of gehlenite. At $700^{\circ} \mathrm{C}$, mayenite $\left(C_{12} A_{7}\right), C_{3} A$ and $\beta-C_{2} S$ (JCPDS card No. 33-302) reflections began to appear. Between $700^{\circ} \mathrm{C}$ and $900^{\circ} \mathrm{C}$, the intensity of mayenite and $\beta-C_{2} S$ reflections increased, and $\mathrm{Ca}_{10}\left(\mathrm{SiO}_{4}\right)_{3}\left(\mathrm{SO}_{4}\right)_{3} \mathrm{Cl}_{2}\left(\mathrm{C}_{10} \mathrm{~S}_{3} \mathrm{~S}_{3} \mathrm{Cl}_{2}\right)$; alinite 


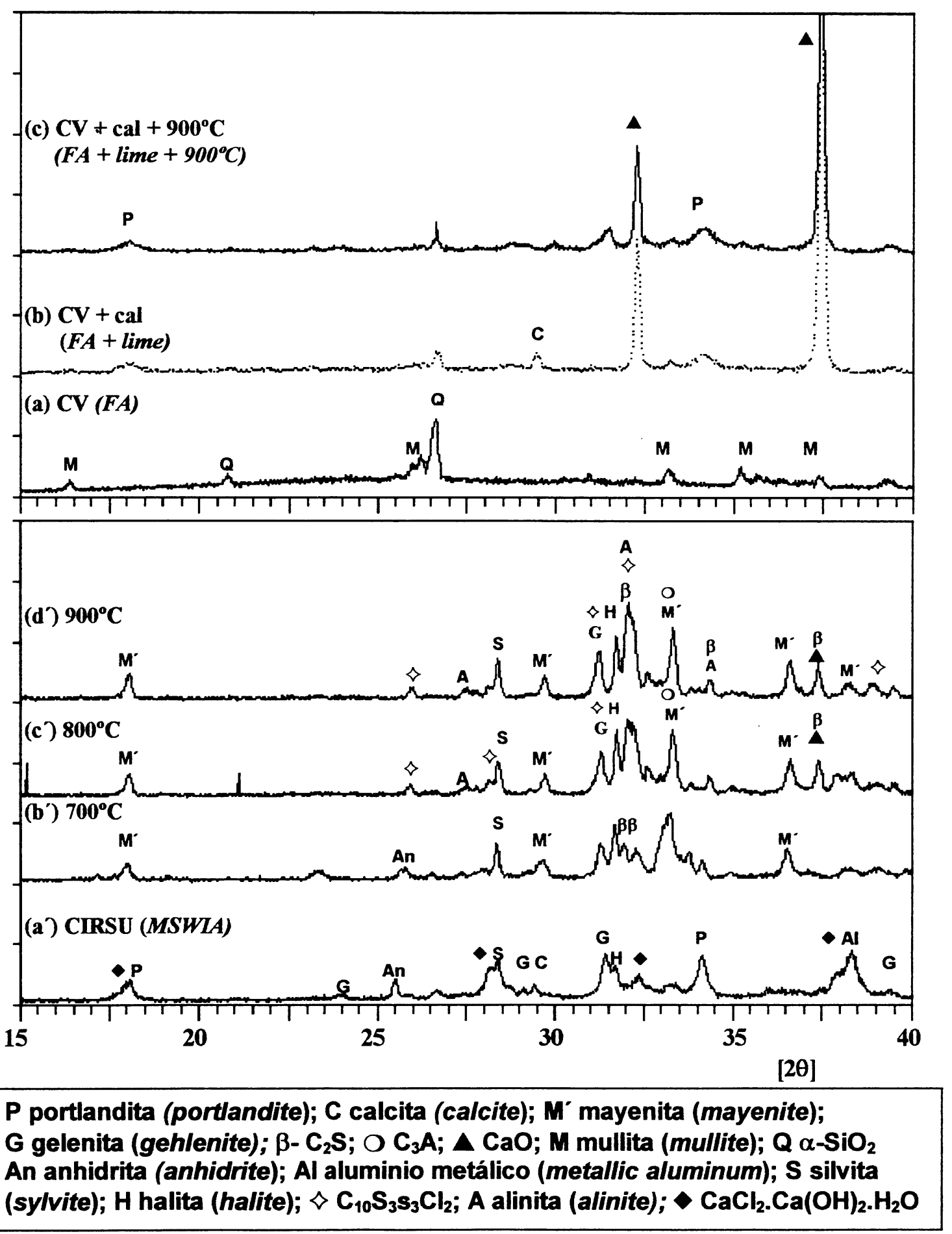

Figura 2.- Evolución de los difractogramas de rayos $\mathrm{X}$ con la temperatura: sin tratamiento hidrotermal.

Figure 2.- Evolution of XRD patterns with temperature: without hydrothermal treatment. 
$\left(\mathrm{Ca}_{10} \mathrm{Mg}_{0.8}\left[\left(\mathrm{SiO}_{4}\right)_{3.4}\left(\mathrm{AlO}_{4}\right)_{0.6} \mathrm{O}_{2} \mathrm{Cl}\right]\right.$ y CaO procedente este último, de la descomposición de la calcita. Más detalles pueden ser consultados en la referencia 24 .

\subsection{Efecto del tratamiento hidrotermal}

Durante el tratamiento hidrotermal de los residuos se forman fases hidratadas, precursoras de los nuevos cementos.

Residuo CV: después de 4 horas de tratamiento hidrotermal del residuo CV (Fig. 3 (b)), desaparecen totalmente las reflexiones de la cal añadida y del cuarzo $\left(\alpha-\mathrm{SiO}_{2}\right)$, formándose los siguientes compuestos cristalinos, resultantes de su reacción puzolánica y precursores del nuevo cemento: $\alpha$ $\mathrm{C}_{2} \mathrm{SH}$, katoita $\left(\mathrm{C}_{3} \mathrm{ASH}_{4}\right)$ la variedad cristalográfica cúbica de la serie hidrogranates, una solución sólida con $\mathrm{Fe}$, de dicha serie $\left(\mathrm{C}_{3} \mathrm{~A}_{0.5} \mathrm{~F}_{0.5} \mathrm{SH}_{4}\right)$, como indican los hombros que aparecen en todas las reflexiones del $\mathrm{C}_{3} \mathrm{ASH}_{4}$ y gel CSH $\left(\mathrm{Ca}_{1.5} \mathrm{SiO}_{3.5} \times \mathrm{xH}_{2} \mathrm{O}\right)$, cuya presencia, aunque dudosa por el solapamiento de las reflexiones de la calcita, fue confirmada por IR y MEB (8). Las reflexiones de calcita y portlandita indican que las cenizas no han reaccionado totalmente con la cal.

Residuo CIRSU: como resultado del tratamiento hidrotermal de la CIRSU, se puede observar, en la (Fig. $3\left(b^{\prime}\right)$ ), que se forman las mismas fases que en el caso de la CV: katoita $\left(\mathrm{Ca}_{3} \mathrm{Al}_{2}\left(\mathrm{SiO}_{4}\right)(\mathrm{OH})_{8}\right.$ $\left(\mathrm{C}_{3} \mathrm{ASH}_{4}\right)$ ) y gel CSH $\left(\mathrm{Ca}_{1.5} \mathrm{SiO}_{3.5} \cdot \mathrm{xH}_{2} \mathrm{O}\right)(\mathrm{JCPDS}$ ficha 33-306).

Además, todas las reflexiones de los compuestos clorados desaparecen sugiriendo su disolución, que ha podido ser constatada por los análisis de iones cloruro efectuados en el líquido, donde su concentración representa el $100 \%$ de la cantidad de cloruro de la CIRSU (22). La principal reflexión del Al metálico (localizada a 38,4 de la zona angular 20) desaparece, indicando que el aluminio se ha disuelto (disolución favorecida por el $\mathrm{pH}$ alcalino $(12,1)$ del medio). Probablemente, el aluminio disuelto se combina como katoita $\left(\mathrm{Ca}_{3} \mathrm{Al}_{2}\left(\mathrm{SiO}_{4}\right)(\mathrm{OH})_{8}\right)$ $\left(\mathrm{C}_{3} \mathrm{ASH}_{4}\right)$. La anhidrita $\left(\mathrm{CaSO}_{4}\right)$ se transforma en $\mathrm{CaSO}_{4} \cdot 0,6 \mathrm{H}_{2} \mathrm{O}$ y la intensidad de las reflexiones de la gelenita $\left(\mathrm{C}_{2} \mathrm{AS}\right)$ y portlandita $(\mathrm{CH})$ permanecen $\sin$ cambios apreciables. La presencia de la fase $\mathrm{Ca}_{15} \mathrm{SiO}_{35} \cdot \mathrm{xH}_{2} \mathrm{O}$ ha sido confirmada por los análisis de espectroscopía infrarroja por la intensa banda de absorción que aparece en $950 \mathrm{~cm}^{-1}(22)$.

Con este tratamiento hidrotermal de la CIRSU, no sólo desaparecen los principales problemas desde el punto de vista de su aplicación a los materiales de
$\mathrm{Ca}_{10} \mathrm{Mg}_{0.8}\left[\left(\mathrm{SiO}_{4}\right)_{3.4}\left(\mathrm{AlO}_{4}\right)_{0.6} \mathrm{O}_{2} \mathrm{Cl}\right]$ and $\mathrm{CaO}$, from calcite decomposition, appeared. More details can be consulted in reference 24.

\subsection{Effect of hydrothermal treatment}

During the hydrothermal treatment of wastes, hydrated phases precursors of the new cements are obtained.

FA: after 4 hours of hydrothermal treatment of the $\mathrm{CaO}$ and $\mathrm{FA}$ mixture (Fig. 3 (b), the $\mathrm{CaO}$ and $\alpha-\mathrm{SiO}_{2}$ reflections disappeared and new are detected, which corresponded to the fly ash pozzolanic reaction products: $\alpha-C_{2} S H$ and katoite $\left(C_{3} A S H_{4}\right)$ (the cubic crystallographic variety of hydrogarnets series). A shoulder appears, in all the $\mathrm{C}_{3} \mathrm{ASH}_{4}$ reflections, at lower value of the $2 \theta$ angular zones, which suggest the presence of solid solution of Fe-katoite $\left(\mathrm{C}_{3} A_{0.5} \mathrm{~F}_{0.5} \mathrm{SH}_{4}\right)$. It was not possible to discover the presence of CSH gel by XRD due to calcite reflections, but it was confirmed from IR and SEM analyses (8). The reflections of calcite and portlandite showed that the fly ash pozzolanic reaction is not completed; although all the fly ash reflections disappeared.

MSWIA: as a result of hydrothermal treatment of MSWIA almost the same phases than those from hydrothermal treatment of $F A$ are formed (Fig. 3 $\left.\left(b^{\prime}\right)\right)$, katoite silication $\left(\mathrm{Ca}_{3} \mathrm{Al}_{2}\left(\mathrm{SiO}_{4}\right)(\mathrm{OH})_{8}\left(\mathrm{C}_{3} \mathrm{ASH}_{4}\right)\right.$ (JCPDS card 38-368) together with those of $\mathrm{Ca}_{1.5} \mathrm{SiO}_{3.5} \cdot \mathrm{XH}_{2} \mathrm{O}$ (JCPDS card 33-306).

The disappearance of starting chloride-compounds suggest its dissolution as was corroborated from the analyses of the aqueous solution, where the concentration of chloride represents near the 100\% of total amount of chloride of starting mixture (22). The disappearance of metallic aluminium reflection at $2 \theta=38.4$ indicates also its dissolution. In fact, the liberated $\mathrm{H}_{2}$ gas was clearly observed as a result of hydrothermal treatment. Dissolved Al together with portlandite and $\mathrm{SiO}_{2}$ combined, probably, as katoite silicaton. Anhydrite (CaSO$)_{4}$ reflections decreased and shifted to higher $2 \theta$ values. The presence of $\mathrm{Ca}_{1.5} \mathrm{SiO}_{3.5} \cdot \mathrm{xH}_{2} \mathrm{O}$ (its $\mathrm{X}$-ray reflections are overlapped with those of calcite), was confirmed from $I R$ analyses by the strong absorption band at $950 \mathrm{~cm}^{-1}(22)$.

Chloride (corrosion) and metallic aluminium (expansion due to its dissolution) represent one of the main problems front the point of view ot its 
construcción (expansión, por la disolución del aluminio metálico y presencia de cloruros, no deseable por los problemas de corrosión de las armaduras metálicas), sino que además se forman unas fases de gran interés, por sus propiedades y aplicaciones como precursoras de los cementos y que vamos a ver a continuación.

\subsection{Evolución de las fases precursoras con la temperatura}

Residuo CV: la deshidratación, por calentamiento de las fases precursoras de los nuevos cementos, se llevó a cabo hasta $900^{\circ} \mathrm{C}$, pues a partir de dicha temperatura se favorecía la formación de gelenita, fase no deseable por su escasa hidraulicidad (8).

A $700{ }^{\circ} \mathrm{C}$ (Fig. 3 (c)), la portlandita, los dos tipos de katoita y $\mathrm{C}_{2} \mathrm{SH}$ desaparecen y comienzan a detectarse nuevas reflexiones anchas que podrían atribuirse a las variedades $\alpha^{6} \mathrm{~L}$ y $\beta$ del $\mathrm{C}_{2} \mathrm{~S}$ junto con $\mathrm{C}_{3} \mathrm{AS}_{3}$ y $\mathrm{C}_{12} \mathrm{~A}_{7}$ (mayenita). A partir de los análisis termogravimétricos de esta muestra se evaluó el contenido en $\mathrm{CaCO}_{3}$ (4,5\% sobre el residuo) y por lo tanto de $\mathrm{CaO} \sin$ reaccionar $(2,6 \%)$.

A $800^{\circ} \mathrm{C}$ (Fig. 3 (d)), la intensidad de las reflexiones de $\alpha^{\prime} \mathrm{L}$ y $\beta-\mathrm{C}_{2} \mathrm{~S}$ aumenta, y empieza a formarse $\mathrm{C}_{3} \mathrm{~A}$. La calcita, como es lógico disminuye considerablemente junto con la fase $\mathrm{C}_{3} \mathrm{AS}_{3}$. No se descarta la presencia de $\mathrm{CaO}$ libre (1,2\%, calculado a partir de los análisis termogravimétricos).

A $900{ }^{\circ} \mathrm{C}$ (Fig. 3(e)), la fase mayenita $\left(\mathrm{C}_{12} \mathrm{~A}_{7}\right)$, calcita y $\mathrm{C}_{3} \mathrm{AS}_{3}$ casi han desaparecido, definiéndose mejor las reflexiones de las variedades $\alpha$ ' $L$ y $\beta-C_{2} S$. A esta temperatura aparece la fase gelenita $\left(\mathrm{C}_{2} \mathrm{AS}\right)$ con unas reflexiones bastantes intensas. $\mathrm{El}$ contenido en $\mathrm{CaO}$ libre de esta muestra, calculada a partir del análisis termogravimétrico es de $0,9 \%$.

Residuo CIRSU: en este caso y a fines comparativos, se ha hecho un estudio equivalente al realizado con el residuo anterior (24).

A $700{ }^{\circ} \mathrm{C}$ (Fig. $\left.3\left(c^{\prime}\right)\right)$ los compuestos hidratados desaparecen, y comienzan a detectarse las mismas fases que en el caso del residuo CV (a excepción de la anhidrita (Cs)), pero con una intensidad de sus reflexiones considerablemente mayor: mayenita $\left(\mathrm{C}_{12} \mathrm{~A}_{7}\right), \mathrm{C}_{3} \mathrm{~A}$, y las dos variedades $\alpha^{\prime} \mathrm{L}$ y $\beta-\mathrm{C}_{2} \mathrm{~S}$ (fichas JCPDS No. 36-642 y 33-302). La intensidad de las reflexiones de la calcita aumenta, probablemente debido a la carbonatación del $\mathrm{CaO}$ (procedente de la descomposición de la portlandita). El contenido de $\mathrm{CaO}(11 \%)$ ha sido evaluado a partir del análisis termogravimétrico, por la cantidad de calcita $(19 \%)$ presente en la muestra. potential valorization towards construction materials. The hydrothermal treatment of MSWIA avoids such problems and in addition precursor hydrated phases of cements are formed.

\subsection{Evolution with temperature of precursor phases}

$\boldsymbol{F A}$ : The dehydration of cement precursors was carried out by heating up to $900{ }^{\circ} \mathrm{C}$ because of at higher temperatures gehlenite was formed which is not desirable from the point of view of its low hydraulicity (8).

At $700{ }^{\circ} \mathrm{C}$ (Fig. 3 (c)), the hydrated precursors disappeared. At this temperature some broad new peaks are detected which could be attributed to $\alpha^{\prime} L$ and $\beta-C_{2} S$, together with $C_{12} A_{7}$ (mayenite), $C_{3} A$ and $\mathrm{C}_{3} \mathrm{AS}_{3}$. The content of $\mathrm{CaCO}_{3}$ (determined from $\mathrm{TG}$ curve) is $4.5 \%$ and the free $\mathrm{CaO}$ is $2.6 \%$.

At $800^{\circ} \mathrm{C}($ Fig. $3(d))$, the intensity of the $\alpha \mathrm{L}-C_{2} S$ and $\beta-C_{2} S$ increased and begins to form $C_{3} A$. Calcite and $C_{3} A S_{3}$ decreased. Besides, the $C_{2} A S$ (gehlenite) begins to appear. The content of free $\mathrm{CaO}$ is $1.2 \%$, determined from the decomposition of $\mathrm{CaCO}_{3}$ in the TG curve.

At $900{ }^{\circ} \mathrm{C}$ (Fig. 3(e)), mayenite, calcite and $C_{3} A S_{3}$ almost disappeared, increasing considerably the intensity of gehlenite; $\alpha$ ' $L-C_{2} S$ and $\beta-C_{2} S$ peaks. some $\mathrm{CaO}$ is also detected whose content was $0.9 \%$.

MSWIA: In this case, for comparative purpose, an equivalent study to that of $F A$ waste was carried out (24).

Sample heated at $700{ }^{\circ} \mathrm{C}$ (Fig. 3 (c')): The reflections of hydrated compounds disappeared. Gehlenite $\left(C_{2} A S\right)$ remains, and begins to be detected the same phases than those of $F A$ waste: mayenite $\left(C_{12} A_{7}\right), C_{3} A$ and the two $\alpha$ 'L and $\beta-C_{2} S$ varieties (JCPDS cards No. 36-642 and 33-302). The intensity of calcite reflections increased strongly due to the carbonation of $\mathrm{CaO}$ from portlandite decomposition. The content of unreacted $\mathrm{CaO}(11 \%)$ was estimated from the $\mathrm{CaCO}_{3}(19 \%)$ by thermogravimetric analysis. 
Entre $700^{\circ} \mathrm{C}$ y $900^{\circ} \mathrm{C}$ (Fig. $3\left(d^{\prime}\right)$ y (e')) se producen los siguientes cambios: la intensidad de las reflexiones de la mayenita y $\alpha^{\prime} \mathrm{L}-\mathrm{C}_{2} \mathrm{~S}$ aumentan, mientras que la intensidad del $\beta-\mathrm{C}_{2} \mathrm{~S}$ y de la calcita disminuye, apareciendo el $\mathrm{CaO}$.

Los cambios más relevantes introducidos por el tratamiento hidrotermal de la CIRSU son los siguientes:

- Ausencia de las fases cloradas tipo:

$\mathrm{Ca}_{10}\left(\mathrm{SiO}_{4}\right)_{3}\left(\mathrm{SO}_{4}\right)_{3} \mathrm{Cl}_{2}$, alinita $\left(\mathrm{Ca}_{10} \mathrm{Mg}_{0.8}\left[\left(\mathrm{SiO}_{4}\right)_{3.4}\left(\mathrm{AlO}_{4}\right)_{0.6} \mathrm{O}_{2} \mathrm{Cl}\right]\right.$, halita y silvita, debido a la disolución de los cloruros durante el proceso hidrotérmico.

- Las fases $\alpha^{\prime} \mathrm{L}$ y $\beta-\mathrm{C}_{2} \mathrm{~S}$ se forman preferentemente, quizás por la deshidratación del gel CSH.

- La cantidad de $\mathrm{CaO}$ libre formado durante el calentamiento es considerablemente mayor. Esto se debe a la ausencia de $\mathrm{Ca}_{10}\left(\mathrm{SiO}_{4}\right)_{3}\left(\mathrm{SO}_{4}\right)_{3} \mathrm{Cl}_{2}$ y alinita, fases de elevado contenido en $\mathrm{Ca}$.

Entre las diferencias introducidas por las características de los residuos están:

- La fase mayenita, que se forma preferentemente en los cementos obtenidos a partir de la CIRSU, y que como veremos a continuación juega un papel relevante en la velocidad de hidratación, alcanzando prácticamente a 1 día el máximo de hidratación.

- La cal libre en esos cementos es también mayor.

. La cristalinidad de las variedades $\alpha^{\prime} \mathrm{L}-\mathrm{C}_{2} \mathrm{~S}$ y $\beta-\mathrm{C}_{2} \mathrm{~S}$ es mayor, como lo demuestra la mayor intensidad de sus reflexiones.

\subsection{Grado de hidraulicidad de los nuevos cementos}

El grado de hidraulicidad de los cementos obtenidos se ha evaluado a partir del agua combinada (por análisis termogravimétrico). Para ello se fabricaron pastas, con los cementos a los que se ha practicado el pretratamiento hidrotermal, con una relación agua/ cemento de 0,8 , similar a la empleada con los cementos belíticos de cenizas volantes (CBCV) (6), que se mantuvieron herméticamente cerradas durante un período de 28 días.

En los perfiles de evolución del agua combinada (Fig. 4), se refleja la rápida hidratación del cemento belítico de incineración de residuos sólidos urbanos (CBIRSU) que, a 1 día, alcanza el máximo, mientras que el CBCV tiene una hidratación mucho más lenta. Sin
Samples heated from $700{ }^{\circ} \mathrm{C}$ to $900{ }^{\circ} \mathrm{C}$ (Fig. 3 (d') and $\left.\left(e^{\prime}\right)\right)$ : The intensity of mayenite reflections and $\alpha^{\prime} L-C_{2} S$ increased as that of $\beta,-C_{2} S$ and calcite decreased, appearing the $C(\mathrm{CaO})$ reflections.

In summary, the more relevant changes caused by the hydrothermal treatment of MSWIA are the following:

- Absence of chloride phases such as:

$\mathrm{Ca}_{10}\left(\mathrm{SiO}_{4}\right)_{3}\left(\mathrm{SO}_{4}\right)_{3} \mathrm{Cl}_{2}$, alinite

$\left(\mathrm{Ca}_{10} \mathrm{Mg}_{0.8}\left[\left(\mathrm{SiO}_{4}\right)_{3.4}(\mathrm{AlO})_{0.6} \mathrm{O}_{2} \mathrm{Cl}\right]\right.$, halite and sylvite, due to the dissolution of chloride during the hydrothermal process.

- The $\alpha^{\prime} L$ and $\beta-C_{2} S$ are preferably formed, perhaps from the dehydration of $\mathrm{CSH}$ gel.

- The amount of free $\mathrm{CaO}$ is considerably higher as a result of the absence of both $\mathrm{Ca}{ }_{10}\left(\mathrm{SiO}_{4}\right)_{3}\left(\mathrm{SO}_{4}\right)_{3} \mathrm{Cl}_{2}$ and alinite phases of great $\mathrm{Ca}$ content.

The main differences introduced by the characteristics of wastes are the following:

- The mayenite, which is preferably formed in the case of cements obtained from MSWLA. This phase plays a very important role related to the hydration rate of cements reaching by one day its maximum.

- The free $\mathrm{CaO}$ is higher.

The crystallinity degree of the $\alpha^{\prime} L-C_{2} S$ and $\beta-C_{2} S$ is higher as confirmed the intensity of their reflections.

\subsection{Hydraulicity degree of the new cements}

The hydraulicity degree of cements, obtained after the hydrothermal treatment of wastes, was evaluated from the combined water content (determined from TG curves). For this, pastes were prepared at a demineralised water to cement ratio of 0.8 , which is similar to that used for $F A B C(6)$. The pastes were maintained for 28 days at $100 \% \mathrm{RH}$.

As can be seen in Fig. 4, the rate of hydration is markedly fast for municipal solid waste incineration ash cements (MSWIAC), compared with that of FABC. So, the combined water content of hydrated MSWIAC reaches the maximum value by one day, irrespective 


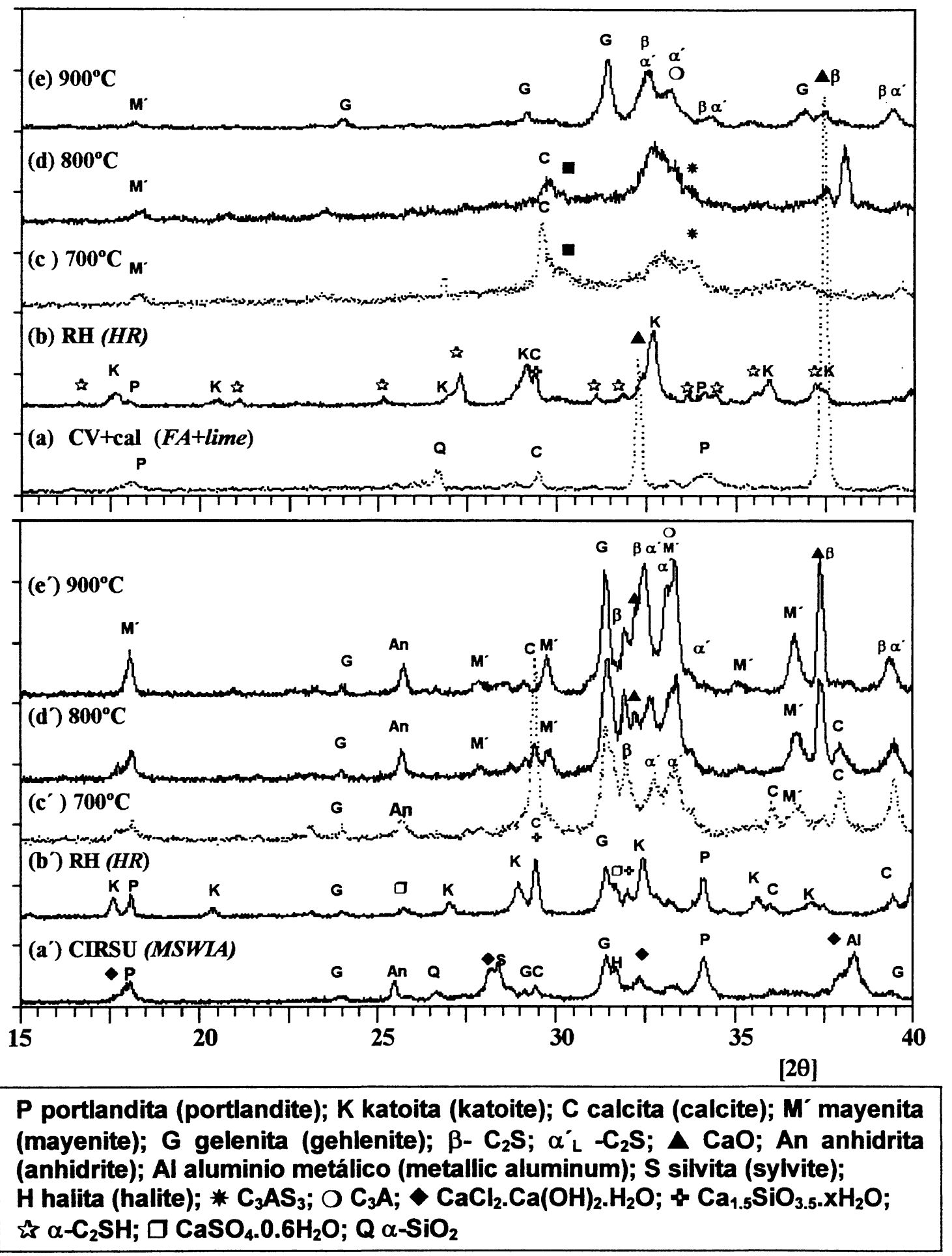

Figura 3.- Evolución de los difractogramas de rayos $\mathrm{X}$ con la temperatura: con tratamiento hidrotermal.

Figure 3.- Evolution of XRD patterns with temperature: with hydrothermal treatment. 

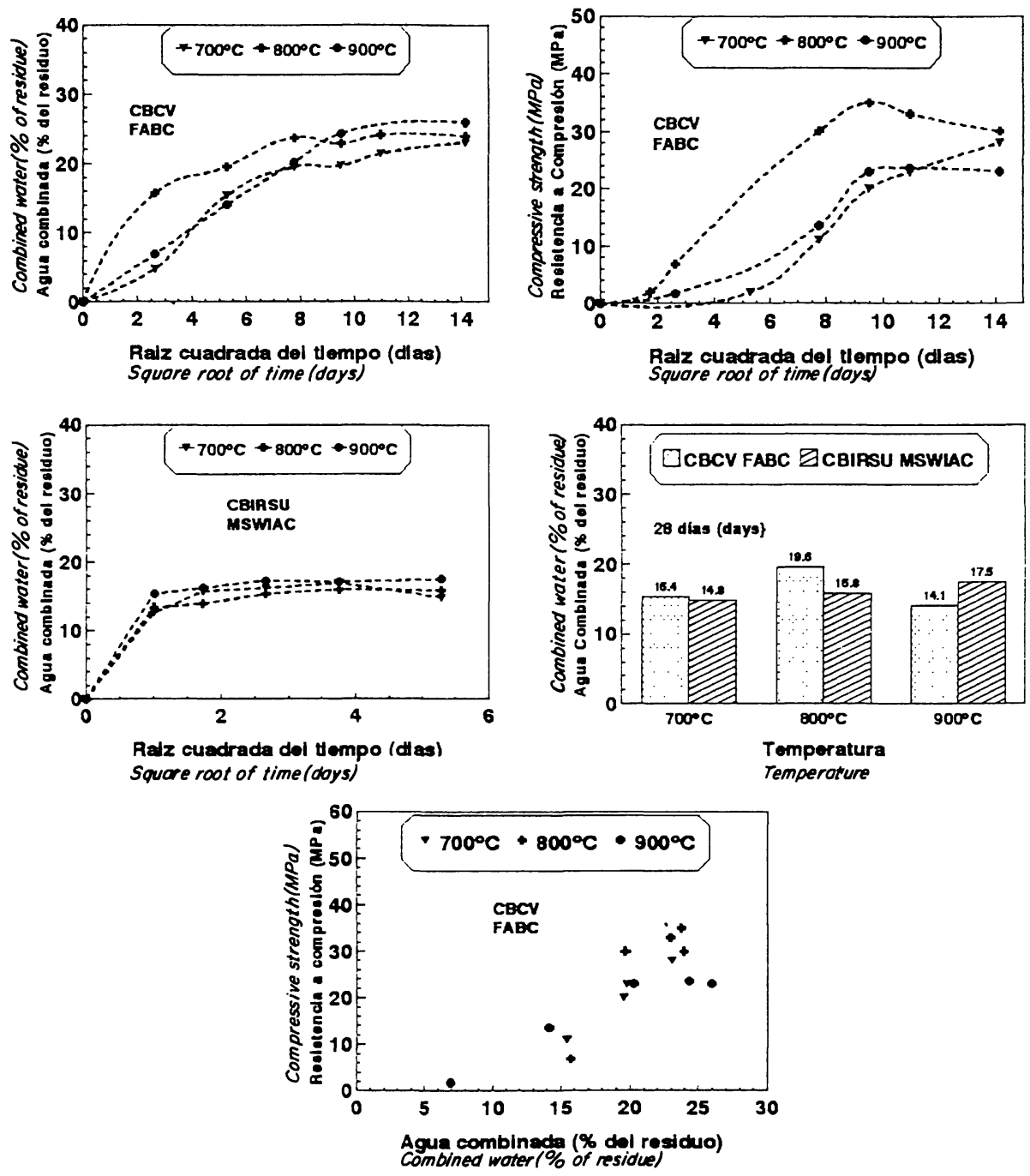

Figura 4.- Grado de hidraulicidad de los nuevos cementos.

Figura 4.- Hydraulicity degree of the new cements.

embargo, si se compara el agua combinada de ambos cementos a 28 días de hidratación, los valores se igualan -o incluso se superan- en el caso del CBCV obtenido a $800^{\circ} \mathrm{C}$. A $900^{\circ} \mathrm{C}$, el CBIRSU combina más cantidad de agua.

En la Fig. 4 se han incluido los valores de resistencia mecánica a compresión de morteros fabricados con el cemento $\mathrm{CBCV}$ (7). El valor de resistencia que alcanza, a los 28 días de hidratación, el $\mathrm{CBCV}$ obtenido a $800^{\circ} \mathrm{C}(30 \mathrm{MPa})$, es equiparable a la del tipo de cemento CEM I-32.5, según las especificaciones de la Norma UNE 80.301-96.

Si se cruzan los parámetros de agua combinada y resistencia mecánica, el perfil de la distribución de puntos sugiere que es a partir de un $7 \%$ de agua combinada cuando estos cementos (CBCV) empiezan a ganar resistencia. of the temperature of synthesis. Nevertheless, the combined water content values of both MSWIAC and $F A B C$ are similar after 28 days of hydration. At $900{ }^{\circ} \mathrm{C}$, $M S W I A C$ combined more water than FABC.

The compressive mechanical strength data of $F A B C$ (7) have been included in Fig. 4, where the FABC synthesised at $800^{\circ} \mathrm{C}$ reached after 28 days of hydration the higher value (30 MPa), which is comparable to that of Spanish Portland CEM I-32.5, according to the specifications of Spanish standard UNE 80.301-96.

The combined water content versus the mechanical strength gives a distribution of points, which suggest that the FABC start to gain strength from $7 \%$ of combined water. 
Basándose en estos resultados y en los valores de agua combinada de los cementos CBIRSU, se puede esperar un comportamiento mecánico similar, pero con una cinética mucho más rápida de ganancia de resistencia, que, a 1 día, alcanzarían el máximo valor.

Por último, se quiere destacar que los resultados del cemento belítico CBIRSU son preliminares y necesitan ser validados no sólo desde el punto de vista mecánico y de durabilidad, sino también medio ambiental. Este último aspecto incluye estudios de lixiviación de los elementos tóxicos minoritarios de la ceniza, que se están realizando actualmente.

\section{AGRADECIMIENTOS}

Los autores agradecen a la Comunidad de Madrid (CAM) y a la CICYT la financiación de los proyectos (07M/0052/1999) (MAT95-0054) (BQU2000-1357) (PB98-0516) у (07M/0560/1997).
On the basis of these results and taking into account the combined water content of MSWIAC, one can expect a similar mechanical behaviour, but with a much fast gain of strength.

These preliminary results need to be completed with mechanical, durability and leaching studies to determine the degree of immobilisation of the minority toxic elements of the cements, which are actually being carried out.

\section{ACKNOWLEDGEMENT}

The authors are grateful for financial assistance from CAM and CICYT Projects: (07M/0560/1997) (07M/0052/1999) (MAT95-0054) (BQU2000-1357) and (PB98-0516).

\section{BIBLIOGRAFÍA}

(1)G. Bernardo, M. Marroccoli, F. Montagnaro and G.L. Valenti. “Calcium Sulphoaluminate Cements Made from Fluidized Bed Combustion Wastes”, Proceedings of Waste Materials in Construction: Science and Engineering of Recycling for Environmental Protection Editors: G.R. Woolley, J.J.M. Goumans and P.J. Wainwright, Pergamon, Amsterdam, pp. 750-758 (2000).

(2) W. Jiang and D.M. Roy. "Hydrothermal Processing of New Fly Ash Cement". Ceramic Bulletin, 71 (4), $642-647$ (1992).

(3) S. Goñi, M.P. Luxán, A. Guerrero, M.S. Hernández and A. Macías. "Microstructural Study of Hydration Reactions of a Fly Ash-Belite Cement", Proc. of Sixth Canmet/ACI International Conference on Fly Ash, Silica Fume, Slag and Natural Pozzolans in Concrete, Bangkok, Ed.: V.M. Malhotra, vol. I, SP-178 pp. 207-224(1998).

(4) S. Goñi, A Guerrero, A. Macías and M.P. Luxán. "Effect of the synthesis temperature on the hydration reaction of fly ash-belite cement". Materials Science of Concrete: The Sidney Diamond Symposium. ISBN: 1-57498-072-6(1998)pp. 93-108.

(5) A. Guerrero, S. Goñi, A. Macías and E. Fernández. "Microstructure of new fly ash-belite cement mortar: Changes provoked by sulphate, chloride and sodium ions". Proceedings of $21^{\text {th }}$ International Conference on Cement Microscopy (1999) pp. 230-237.

(6) A. Guerrero, S. Goñi, A. Macías and M.P. Luxán "Hydraulic Activity and Microstructural Characterization of New Fly Ash-Belite Cements Synthesized at Different Temperatures”, J. Mater. Res., vol. 14, No. 6, pp. 2680-2687 (1999).

(7) A. Guerrero, S. Goñi, A. Macías and M.P. Luxán. "Mechanical Properties, Pore-Size Distribution and Pore Solution of Fly Ash-Belite Cement Mortars.",Cem. Concr. Res., Vol. 29, pp. 1753-1758 (1999).

(8)S. Goñi, A. Guerrero, M.P. Luxán and A. Macias. "Dehydration of pozzolanic products hydrothermally synthesized from fly ashes. Microstructure evolution". Materials Research Bulletin (2000) 35(8), pp. 1333-1344.

(9) A. Guerrero, S. Goñi, A. Macías and M.P. Luxán. "Effect of the starting fly ash on the microstructure and mechanical properties of fly ash -belite cement mortars". Cement and Concrete Research (2000) Vol. 30(4), pp. 553-559.

(10) A. Guerrero, S. Goñi and A. Macías. "Durability of new Fly ash-Belite Cement Mortars in Sulfated and Chloride Medium", Cem. Concr. Res., Vol. 30 (8) pp. 1231-1238(2000).

(11) M. Singh, M. Garg. “Cementitious binder from fly ash and other industrial wastes”, Cem. Concr. Res., Vol 29(3) pp. 309-314 (1999).

(12)P. Arjunan, Michael R. Silsbee, Della M. Roy. "Sulfoaluminate-belite cement from low-calcium fly ash and sulfur-rich and other industrial by-products" Cem. Concr. Res., Vol 29 (8) pp. 1305-1311 (1999).

(13) P.J. Wainwright and P. Robery. "Production and Properties of Sintered Incinerator Residues as Aggregate for Concrete". Waste Materials in Construction, J.J.J.R. Goumans, H.A. Van der Sloot and Th.G. Aalbers(Editors). Elsevier Science Publisher, pp. 425-432 (1991). (14) J. Pera, L. Coutaz, J. Ambroise and M. Chababbet. "Use of Incinerator Bottom Ash in Concrete”. Cem. Concr.. Res, Vol. 27, No 1, pp. 1-5(1997).

(15) M.T. Ali and W.F. Chang. "Strength Properties of Cement Stabilized Municipal Solid Waste Incinerator Ash masonry Bricks", ACI Materials Journal, Vol.91, No 3,pp. 256-263(1994).

(16) D.L. Gress, X.Zhang, S. Tarr, I. Pazienza and T.T. Eighmy. "Municipal Solid Waste Combustion Ash as an Aggregate Substitute in Asphaltic Concrete". Waste Materials in Construction, J.J.J.R. Goumans, H.A. Van der Sloot and Th.G. Aalbers(Editors). Elsevier Science Publisher,pp. 161-175(1991).

(17) D.J. Nonneman, F.A. Hansen and M.H.M. Coppens. “The Use of Incinerator Slag in Asphalt for Road Construction”. Waste Materials in Construction, J.J.J.R. Goumans, H.A. Van der Sloot and Th.G. Aalbers (Editors). Elsevier Science Publisher, pp.569-578 (1991). 
(18) C. Crignon, G. Pecqueur and E. Garcia Diaz. "Study of Cement-Treated MSWI Bottom Ash Expansion". Proc. of International Conference on Waste Stabilisation and Environment, Ed.: Société Alpine de Publications, pp. 64-68 (1999).

(19) M.M.C. Alkemade, M.M.Th. Eymael, E. Mulder and W. De Wijs. "How to Prevent Expansion of MSWI Bottom Ash in Road Construction? Environmental Aspects of Construction with Waste Materials, JJJM Goumans, HA. Van der Sloot and ThG. Aalbers(Editors), p. 863-876(1994).

(20) O. Barbery and A. Ghodsi. "Trapping of Chloride, Sulfate and Heavy Metals", Proc. of the International Symposium on Sustainable Construction: Use of Incinerator Ash. Ed. by Ravindra K. Dhir, Tom D. Dyer and Kevin A. Paine, Publishers Thomas Telford, London, pp. 173-183(2000).

(21) A. Nzihou and P. Sharrock. "Extraction of Chloride from Fly Ash and Stabilisation of the Residues by a Hydroxylapatite Sol-Gel Process", Proc. of International Conference on Waste Stabilisation and Environment, Ed.: Société Alpine de Publications, pp. 30-35 (1999). (22) A. Guerrero, E. Fernández, A. Macías and S. Goñi, "Hydrothermal Treatment of Fly Ash from Municipal Solid Waste Incineration", Proceedings of Waste Materials ín Construction: Science and Engineering of Recycling for Environmental Protection, Editors: G.R. Woolley, J.J.M. Goumans and P.J. Wainwright, Pergamon, Amsterdam Vol. 1, pp.178-185 (2000). ISBN: 0-08-043790-7.

(23)A. Guerrero, S. Goñi, E. Fernándezand A. Macías. "Valorization of Fly Ash from Municipal Solid Waste Incineration Via Hydrothermal Treatment" Seventh CANMET/ACI International Conference on Fly ash, Silica Fume, Slag and Natural Pozzolans in Concrete. Editor by V.M.Malhotra; vol. 1,pp. 295-306(2001).

(24) A. Guerrero, S. Goñi, A. Macías and E. Fernández. "Influence of synthesis temperature on the hydration of new cements from fly ash of municipal solid waste incineration". To be presented in the CANMET/ACI International Symposium on Sustainable Development and Concrete Technology. September 16-19, 2001, San Francisco, EE UU.

(25)Y. Takuma, Y. Tsuchida and S.Uchida. "Characteristics and Hydration of Cement Produced from Ash from Incinerated Urban Garbage", Proceedings of the $10^{\text {th }}$ International Congress on the Chemistry of Cement, vol.3, pp. 3ii1 18, Gothenbirg, Sweden, june 2-6(1997).

(26) H. Motzet and H. Pöllmann. "The Usage of Alinite Cement for Waste Stabilization". International Congress on Waste SolidificationStabilization Processes. Nancy. France (1995).

(27) Takahashi, Hiroaki; Maruta, Toshihisa; Sakae, Kazumasa; Kasahara, Masaru. “Application of water-washed incineration fly ashes as cement raw material". Muki Materiaru, 5 (274), pp 200-207 (1998).

(28)Kasahara, Masaru; Takahashi, Hiroaki; Sakae, Kazumasa; Maruta, Toshihisa. "Desalinizing of incineration ash and recycling as cement raw material by washing with water”. Chichibu Onoda Kenkyu Hokoku, 49 (2), 129-138(1998). 